процесі вищої школи, так і в процесі викладання англійської мови. Протягом багатьох років фахівці в галузі освіти прагнули розробити наочну і доступну теорію, яка, з одного боку, допомогла б педагогам в ефективному і систематичному розвиткові у студентів навичок письма/читання на заняттях з англійської мови, а з іншого, - сприяла б правильній постановці педагогічних цілей у навчанні англійській мові. Найвідомішою моделлю, яка описує як процес набуття знань, так і цілі освіти, є таксономія Блума (Bloom’s Taxonomy), що включає в себе шість навичок мислення, або педагогічних цілей навчання, представлених від базового до найвищого рівня. В умовах сучасного інформаційного суспільства таксономія Блума викликає новий сплеск дослідницького інтересу, адже ії можна розглядати в якості основної концепції в сучасній теорії навчання i, зокрема, в галузі розвитку навичок академічного письма/читання на заняттях з англійської мови. Вона дозволяє одночасно враховувати рівень складності у навчанні англійської мови і дає можливість не тільки переходити від одного рівня складності до іншого, а й стежити за прогресом учнів саме у цій галузі знання за умови наступності в типах і організації завдань. Мета таксономії Блума у викладанні англійської мови - мотивувати педагогів фокусуватися на всіх трьох сферах (когнітивній, афективній і психомоторній), пропонуючи, таким чином, найбільш повну форму навчання.

Ключові слова: освітній процес, процес мислення, педагогічне цілепокладання, таксономія Блума, вища освіта, рівні засвоєння знань, когнітивна область, навчальна діяльність, навички академічного письма/читання, заняття з англійської мови, знання, розуміння, застосування, аналіз, синтез, оцінювання.

Submitted on February, 24, 2017

Reviewed by Doctor of Pedagogy, prof. T. Kharchenko

UDC: $378.147: 811.111$

DOI: https://doi.org/10.24195/2414-4665-2017-2-19

Svitlana Pampura,

PhD (Candidate of Linguistic Sciences), Department of Foreign Languages, Donbas State Pedagogical University, 19, G. Batiuka Str., Sloviansk, Ukraine

\title{
THE CASE STUDY METHOD AS A MEANS OF INCREASING MOTIVATION OF STUDENTS MAJORING IN PSYCHOLOGY FOR LEARNING ENGLISH
}

The article deals with the issue of teaching English for students majoring in non-linguistic specialities. The review of theoretical resources has shown that the modern level of intercultural communication demands transformation in the system of vocational training for students of non-linguistic specialities and introduction of multidimensional teaching of foreign languages for special purposes. It has been stated that motivation for learning English is an essential factor in the process of successful development of professional competences. The use of the case study method in teaching English has proved its effectiveness for increasing motivation and creating good opportunities for implementation of interdisciplinary links.

Key words: foreign language teaching, innovative technologies, professional competence, motivation of students majoring in non-linguistic specialities, case study method, interdisciplinary links.

\section{Introduction}

The current state of the international relations of Ukraine requires considerable changes of the educational system. The issue of socialization of young people in interethnic and intercultural space acquires special significance and causes the necessity of developing new approaches to foreign language teaching. Knowledge of a foreign language is considered as one of the means to expand the professional competence and skills of students. University graduates should master a foreign language at the level sufficient for their professional and personal communication. Nowadays a good level of English enlarges greatly applicants' chances to find an interesting and well-paid job, to get a promotion, to enjoy close relations with business partners. Therefore, efficient teaching and high quality of the knowledge acquired are in urgent need. Today teachers face the task not only to provide students with linguistic knowledge but to form special competence necessary for their future work.

Though the issue of English teaching has been studied by many scholars: D. A. Wilkins, H. G. Widdowson, N. D. Glazkova,T. Yu. Zagriazkina,G. A. Kytaigorodskai a and others - it should be recognized that the level of fluency in foreign languages of university graduates does not always meet modern requirements. Needless to say that the success achieved depends considerably on the degree of the students' motivation. And if students of philological faculties are clearly motivated in studying 
languages, the purpose of learning languages is not always evident for students of non-linguistic specialities. One of the important tasks for English teachers at nonlinguistic universities is to uphold students' motivation for learning the language. This fact stipulates the relevance of the issue.

This article aims to analyze the importance of nontraditional ways of teaching English, and the case study method in particular, for increasing interest in studying the language by students majoring in non-linguistic specialities. The tasks set in the paper are as follows:

to clarify the notion of motivation to learn the English language and modern ideas on the ways of its increasing in the educational process;

to review and analyze the latest scientific studies concerning teaching English for students of non-linguistic specialities;

to approve the effectiveness of the use of the case study method for getting students majoring in psychology more motivated in learning English.

Motivation is often defined as a psychological quality which encourages a person to realize his/her goals [1: 47]. In education, motivation is considered as an undoubted success factor. It is the starter for any kind of activities, whether it is work, communication or learning. According to P. M. Jakobson, there are three types of learning motivation. The first one is so-called "negative motivation", which implies that student study in order to avoid punishment or other consequences. The second one is that of positive character but which is not related to the learning process. It is based on social aspiration significant for a person which results in treating learning as the way to achieve certain purposes. It is this type, which stimulates students to overcome challenges and to prove their diligence. Still, being the most valuable motivation, it will not drive to an optimum effect if not strengthened by other factors. Finally, the last type of motivation is based on the students' personal motives: appreciation of close relatives and friends, the way to personal wellbeing, etc. P. M. Jakobson asserts the process of acquiring knowledge itself as encouraging to study. Students enjoy the learning process and the results of cognitive activities, of discovering the new and fulfilling themselves [4]. Therefore, learning impulse is determined by its goals.

R. C. Gardner distinguishes variables effective in a successful language learning such as "attitudes and motivation, language anxiety, self-confidence, field independence, personality variables ..., intelligence, language aptitude, and language learning strategies" and considers motivation as "a central element along with language aptitude in determining success in learning another language in the classroom setting" [6:3-4].

In our research we understand motivation as a system of external and internal motives of students to learn, which influences their cognitive activities. To keep up a high degree of students' motivation a teacher should be aware of their interests and motives to study (cognitive, professional, entertaining, etc). A positive emotional attitude to the learning process is an important factor as well. Thus, students' motivation is conditioned by considering students' personal interests, teaching methods and technologies used in the classwork.

Nowadays foreign language teachers face the problem of developing extensive knowledge and relevant skills with limited classroom hours available as most non-linguistic faculties provide two-year Foreign Language courses with two (if not fewer) academic hours per week. It can be solved to some extent by students' out-of-class work. However, it is efficient only in case if students have necessary skills and knowledge [5: 18] and are highly motivated. Teaching experience shows that making the learning process interesting and entertaining is not always effective enough for creating "durable" motives in students. It is the direct interrelation between the knowledge acquired and the future professional activities which matters.

Globalization of English as the main intercultural language, the demands for training modern engineers, ITspecialists, psychologies, economists, managers and other professionals mastering modern advanced technologies, the need for communication (placing orders for equipment supply, studying operating instructions, dealing with foreign business partners, etc.) set new goals in the professional English teaching. In fact, last century foreign language training was not aimed at the practical use of language skills in situations of real communication. The education process was regulated by normative documents and standards.

Modern level of intercultural communication demands transformation in the system of vocational training for students of non-linguistic specialities and introduction of multidimensional teaching of foreign languages for special purposes. In the traditional process of learning foreign languages, which involves acquiring knowledge in artificial situations, students are not able to see the bonds between the subject and their future professional activities. Modern researchers assume attaining mutual understanding rather than accuracy as the primary purpose of English teaching for students of non-linguistic specialities [3: 65]. It should be considered that teaching English for specific purposes is to be targeted at integration of communicative skills and language knowledge into a thematic and situational context of a certain professional field. Today, the learning of English means no longer the study of its speakers' language, but the language of intercultural communication which enables speakers of different languages and cultures to understand each other.

The method of teaching English based on cramming words and slogging away grammar is not appropriate in the modern system of foreign language teaching, which causes the necessity to search for a model of teaching considering the specific character of every profession which is based on systemic methods and means aimed at the development of speaking skills contributing to the effective international communication. Today more and more teachers prefer using the communicative method of English teaching. The objective matter of this method is 
speech itself, whose ultimate goal is communication. This method implies involving all students into simultaneous work, creating real communicative situations. Some tasks of problematic character, proposed to the group by a teacher, and lack of time for their solving contribute to the students' mental and academic activities.

Currently, the key issue of English teaching for students of non-linguistic faculties is the complex use of foreign language skills in solving real professional problems and practical tasks. "Foreign Language" turns out to be a discipline that can enrich the content of professional education. It creates the opportunity to implement the interdisciplinary links between the professional subjects and the English language on the basis of the case study method.

In order to understand the degree of motivation for learning English, students majoring in non-linguistic specialities were offered to fill in a questionnaire, in which they had to choose the level of the importance of having a good command of the English language in their future work:

absolutely necessary: it is an essential part of their set of knowledge and skills needed for carrying out their future professional activities (3\%);

extremely desirable: it may be useful in their future education abroad or in getting career promotion (19\%);

- quite desirable: it is important to be a many-sided person and to have basic knowledge in all fields (43\%);

- unnecessary: it does not concern their future work as they are not going to deal with English-speaking people $(35 \%)$.

The results of the survey confirmed the necessity to implement new methods in order to motivate students to get involved into the process of learning English. Thus, to assess the effectiveness of case study method for increasing motivation to study the English language students majoring in Psychology were divided into experimental and control groups.

This method is applied as follows: having studied and analyzed a problematic professional situation, students present their variant(s) of solution and possible sequence of events. Being based mostly on authentic material presenting real problems to be analyzed and solved, it is an integral professional approach which develops reading, writing, speaking and listening skills.

A case involves presenting a real situation, concrete tasks to the case and some additional information for the analysis. The students were divided into some groups of three-five students who acted like experts in practical psychology and were offered the following tasks:

1) Make-up a psychological portrait of a famous person (actor, singer, politician, etc.) and explain the grounds of his/her success. Use information from reliable sources in the Internet, newspaper articles, TV news and so on. Give an attempt to foresee his/her future career opportunities.

2) During your school practice find a problem child. Find out all the information necessary (character features, interests / hobbies, background, family relations, etc.) to understand the reasons of his/her behaviour. Present your plan to change him/her.

3) A world-famous European company is going to start business in the Eastern countries. A group of experts in psychology is hired to make up the start-up crew to implement their project. The detailed personal characteristics of the company-workers are given to be selected for the vacancies.

Needless to say that the case should be thoroughly thought over by the teacher. The command of the language in a group, students' scientific interests and the specific character of the future profession should be taken into account. It is preceded by reading special texts on similar problems, learning new and necessary terms. The information presented in a case should correspond to the students' knowledge for a certain moment [2]. It is important to create didactic and psychological conditions which promote students' cognitive activities, develop their communicative abilities, contribute to their intellectual, personal and social activities, support positive emotional environment in the classroom.

Therefore, at the first stage of the experiment the level of the students' command of the language was estimated. Accordingly, methodical material was prepared to gain awareness of specific problems on the subject and to form required skills. Then, the expert teams were created considering the level of their competence in the subject and personal relations among the students.

To present their solutions the students were supposed to define and analyze the problem; to learn all the material presented and to search for the additional information; to think over the variants of the problem solution and to discuss them with the team in order to generate the common most reasonable idea.

The teacher guides the whole process, directs the discussion, generates questions and fixes the answers. It is the teacher who makes the opening, address and final speech, creates the businesslike atmosphere, makes decisions on the objectivity and optimality of the solutions [2].

It was up to the students whether to present their solutions in a Power Point presentation or in a written report. It should be considered that a case cannot have a simple and unique solution. All the solutions had their strengths and weaknesses. In the discussion every team had to suggest its own variant and to convince others in the validity of their assumptions.

After the experiment the students were offered to fill in the same questionnaire they had filled in before. The results have changed in the following way: the students considered having a good command of the English language in their future work as:

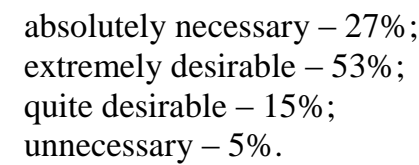

The results of the experiment are presented in the table 1 . 
Table 1.

The level of students' motivation to learn English

\begin{tabular}{|c|c|c|c|c|}
\hline \multirow{2}{*}{ Degree of motivation } & \multicolumn{2}{|c|}{ Before the experiment } & \multicolumn{2}{c|}{ After the experiment } \\
\cline { 2 - 5 } & Number & Percentage & Number & Percentage \\
\hline High & 2 & 3 & 17 & 27 \\
\hline Below the average & 11 & 19 & 34 & 53 \\
\hline Low & 28 & 43 & 10 & 15 \\
\hline Total & 23 & 35 & 3 & 5 \\
\hline
\end{tabular}

The results demonstrate that a number of students with high or above the average degree of motivation for learning English for their future work in the field of practical psychology has considerably increased. The students mentioned that the case study method enabled them to use their language competences in professional communication. Learning speciality related material aroused more interest in studying English. The students had to search for information concerning their professional field which had not been studied in the Practical Psychology course and, thus, obtained important knowledge in their speciality. At the same time, it contributed to the improvement of their skills in reading scientific literature, widening their vocabulary with professional terminology and special idiomatic expressions.

\section{Conclusions}

It should be concluded that the case study method is an effective means to get students majoring in non-linguistic specialities motivated to learn English. It creates good opportunities to form competences necessary for students' work in the future: skills to search for and analyze information, work in teams, make reports and solutions in standard and non-standard situations and to present them to the audience, to argue their position, to take the responsibility for the results, etc. It allows students to display their professional knowledge in practice. In addition, it involves mastering new vocabulary, idiomatic expressions, syntactic structures and, thus, improvement of the students' command of the English language.

Our further research is planned to deal with non-traditional integrated classes, in particular binary classes.

\section{REFERENCES}

1. Goncharenko, T. Ye. (2010). Motyvatsiia vyvchennia inozemnoii movy yak sotsialna funktsiia osvity [Motivation at studying foreign languages as education social function]. Teoriia i praktyka upravlinnia sotsialnymy systemamy: filosofiia, psykholohiia, pedahohika, sotsiolohiia - Theory and practice of social systems management: philosophy, psychology, sociology, 4, 47-55 [in Ukrainian].

2. Zolotova, M. V. \& Demina, O. A. (2015). O nekotorykh momentakh ispolzovaniia metodov keisov $\mathrm{v}$ obuchenii inostrannomu yazyku [Concerning some aspects of using the case study method in teaching a foreign language]. Teoriya i praktika obshchestvennogo razvitiya - Theory and practice of social development, 4. Retrieved from: http://teoriapractica.ru/rus/files/arhiv_zhurnala/2015/4/pedagogics/zol otova-demina.pdf [in Russian].

3. Kuznetsova, O. Yu. (2015). Aktualni aspecty modernizatsii inshomovnoii osvity [Relevant aspects of foreign languages teaching modernization]. Proceedings from V Mizhnarodna konferentsiia «Suchasni pidkhody do navchannia inozemnoii movy: shliakhy integratsii

\section{ЛIТЕРАТУРА}

1. Гончаренко Т. Є. Мотивація вивчення іноземної мови як соціальна функція освіти / Т. С. Гончаренко // Теорія і практика управління соціальними системами: філософія, психологія, педагогіка, соціологія. - 2010. - № 4. - С. 47-55.

2. Золотова М. В. О некоторых моментах ис- shkoly ta vnz» - Proceedings from the fifth international conference "Modern Approaches to Foreign Language Teaching: Ways of School and University Integration» (pp. 64-65). Kharkiv [in Ukrainian].

4. Yakobson, N. V. (1969). Psikhologicheskiie problemy motivatsii v povedenii cheloveka [Psychological Problems of Motivation in Human Behaviour]. Moscow: Prosveshcheniie [in Russian].

5. Yaremenko, N. V. (2016). Deiaki shliakhy intensyfikatsii vykladannia angliiskoii movy studentam nemovnykh spetsialnostei [Some Ways of Intensification of English Teaching to Students of Nonlanguage Specialities]. Aktualni problemy pedahohiky, psykholohii ta profesiinoi osvity - Relevant issues of Pedagogy, Psychology and Professional Education, 1. Retrieved from: http://journals.uran.ua/apppfo/article/view/61824/57569 [in Ukrainian].

6. Gardner, R. C. Language Learning Motivation: The Student, the Teacher, and the Researcher. - Retrieved from: http://files.eric.ed.gov/fulltext/ED464495.pdf [in English].

пользования методов кейсов в обучении иностранному языку [Електронний ресурс] / М. В. Золотова, О. А. Демина // Теория и практика общественного развития. - 2015. - № 4. - Режим доступу: http://teoriapractica.ru/rus/files/arhiv_zhurnala/2015/4/pedagogics/zol otova-demina.pdf 
3. Кузнецова О. Ю. Актуальні аспекти модернізації іншомовної освіти / О.Ю.Кузнецова // Тези доповідей V Міжнародної конференції «Сучасні підходи до навчання іноземної мови: шляхи інтеграції школи та ВНЗ» (17 квіт. 2011 р.). - Харків, 2015. C. 64-65.

4. Якобсон П. М. Психологические проблемы мотивации в поведении человека : науч. изд. / П. М. Якобсон. - М.: Просвещение. - 1969. - 317 с.

5. Яременко Н. В. Деякі шляхи інтенсифікації викладання англійської мови студентам немовних спеціальностей [Електронний ресурс] / Н. В. Яременко // Актуальні проблеми педагогіки, психології та професійної освіти. - 2016. - № 1 - Режим доступу: http://journals.uran.ua/apppfo/article/view/61824/57569

6. Gardner R. C. Language Learning Motivation: The Student, the Teacher, and the Researcher [Електронний pecypc] / R. C. Gardner. - Режим доступу: http://files.eric.ed.gov/fulltext/ED464495.pdf

Світлана Юріївна Пампура, кандидат філологічних наук, доиент кафедри іноземних мов, ДВНЗ «Донбаський державний педагогічний університет», вул. Г. Батюка, 19, м. Слов'янськ, Украӥна

\section{МЕТОД ВИВЧЕННЯ КЕЙСІВ ЯК ЗАСІБ ПІДВИЩЕННЯ МОТИВАЦІЇ СТУДЕНТІВ ДО ВИВЧЕННЯ АНГЛІЙСЬКОЇ МОВИ}

Нові запити вищої освіти, пов'язані з інтеграцією України в Свропейський простір, зумовили перегляд вимог до професійної підготовки майбутніх фахівців. Знання іноземної мови наразі розглядається як засіб, що сприяє розширенню професійної компетенції та фахових навичок студентів. Тому використання інноваційних методів навчання іноземних мов у вишах для студентів немовних спеціальностей набуває все більшої значущості. Важливою причиною недостатнього рівня володіння англійською мовою студентами немовних спеціальностей є низька мотивація до ії вивчення, що й створило актуальність дослідження. Метою статті є аналіз якостей, необхідних для успішного оволодіння студентами іноземною мовою на рівні, достатньому для втілення їх професійних компетенцій, та шляхів поліпшення навчання іноземної мови студентів немовних спеціальностей. У статті розкриваються сутність поняття мотивація та сучасні ідеї щодо шляхів ії підвищення; подано огляд й аналіз останніх наукових досліджень з проблеми навчання англійської мови для студентів немовних спеціальностей; доведено ефективність застосування методу вивчення кейсів 3 метою формування високої вмотивованості студентів до вивчення англійської мови професійного спілкування. Мотивацію було визначено як систему зовнішніх і внутрішніх мотивів, що спонукають студента навчатись і впливають на його/їі пізнавальну діяльність. Обізнаність викладача щодо особистих інтересів студентів та їх мотивів навчатись (пізнавальні, професійні, розважальні тощо) сприяє підтриманню високого рівня вмотивованості до навчання. Навчання іноземної мови за професійним спрямуванням має бути спрямованим на інтеграцію комунікативних знань та навичок у тематичний та ситуативний контекст певної професійної галузі. Дисципліна «Іноземна мова» створює умови для втілення міждисциплінарних зав'язків, а застосування методу вивчення кейсів сприяє формуванню іншомовної професійної компетенції. Метод вивчення кейсів дає можливість студентам продемонструвати свої професійні навички на практиці. У статті наведено приклади кейсів, які було апробовано на заняттях зі студентами, які вивчають практичну психологію за фахом. Спостереження впродовж експерименту засвідчили, що цей метод не тільки є ефективним для підвищення мотивації студентів, але також сприяє розвитку таких професійних компетенцій, як покращення рівня володіння мовою, формування навичок командної роботи, розвиток аналітичного мислення, вміння обгрунтовувати своє рішення тощо.

Ключові слова: навчання іноземних мов, інноваційні технології, формування іншомовної професійної компетенції, мотивація студентів немовних спеціальностей, метод вивчення кейсів, інтегровані заняття, міждисциплінарний зв'язок.

Reviewed by Doctor of Pedagogy, prof. I. Tatianchikova 